DOI: $10.2478 /$ auseur-2021-0013

\title{
Dobruja's Public Administration and Its Role in the Romanian Nation- and State-Building Process (1878-1926)
}

\author{
Ernő-Loránd SZABADI
}

PhD student, National University of Public Service - Ludovika, Budapest, Hungary Doctoral School of Public Administration Sciences

e-mail: szabadi_erno@yahoo.com

\begin{abstract}
The paper is devoted to providing a schematic presentation of the evolution of Dobruja's administrative-territorial system as part of Romania, presenting and highlighting the factors that contributed to the Romanian nation- and state-building process. As its primary objective, the study describes the evolution and conscious development of the abovementioned region as part of Romania between the years 1878 and 1926. Also, it formulates as a secondary goal the impact of Dobruja's numerous administrative-territorial reorganizations on the fate of the multicultural community living in the region. At the same time, the aim is also to list and emphasize the strategies, procedures of assimilation, integration, and colonization of the region.
\end{abstract}

Keywords: Dobruja, public administration history, Romanian nation- and state-building

\section{Introduction}

Dobruja is a land between the Danube and the Black Sea that is geologically connected to the Balkans. In terms of its precise geographical delimitation, it is surrounded on the north and the west by the Danube Delta and the Danube shore, on the east by the Black Sea coast, and on the south by the boundaries of Silistra and Dobrich counties on the Bulgarian mainland (Iordachi 2000). In ancient times, the region called Scythia Minor (or Lesser Scythia) was located in approximately the same area as today's historical region of Dobruja, the total area of which is now divided between Romania and Bulgaria (Szabó 2014: 27-36). The area of North Dobruja, which now forms part of Romania and includes two counties, has 15,570 $\mathrm{km}^{2}$, while the area of South Dobruja (Cadrilater) including two counties, which 
are under Bulgarian jurisdiction, is 7,565 $\mathrm{km}^{2}$ (Cociu 1993: 11). The region came under Romanian and Bulgarian rule in 1878, after the 1877-78 Russo-Turkish war had ended, having signed the peace treaty in the Turkish San Stefano, ${ }^{1}$ a treaty that was confirmed by the Congress of Berlin with a significant number of amendments (Balla 1998: 4-9). At that time, 70\% of Dobruja's population was still of TurkishTatar origin (Tóth S. 2009: 21).

The main issues related to Dobruja in the 1878-1926 period are the ethnic composition as well as the sociology of the region, the Romanian nationalization historiography and its symbolic role in nation- and state-building process, and the administrative-territorial reorganization strategies in correlation with cultural and educational policies. We can define nation-state as a form of political organization under which a relatively homogeneous people inhabits a sovereign state (MerriamWebster 2021). Processes and strategies leading up to the establishment of a nationstate are often referred to as nation-building and state-building. The difference between these two terms could be found in the soft and hard aspects of state construction, a distinction which is commonly used in political science literature too (Birch 1989: 40). Nation building in my usage pertains to the soft aspects of establishing a state, which includes construction of a shared identity, sense of unity in the state's population, and the implementation strategies of identity consolidation. State building, in contrast, concerns only the hard aspects of state construction such as the administrative, economic, and military groundwork of functional states (Brubaker 1996: 80-83). Romania and, generally speaking, the 'national' territorial Balkan states of the $19^{\text {th }}-20^{\text {th }}$ centuries were validly created from the partitioning of the Ottoman Empire by Britain, France, Russia, and Austria through the mechanism of the Berlin Treaty of 1878. The purpose of the establishment of these independent and autonomous nation-states was to avoid another all-out war between the above-mentioned powers. So, creating these new 'artificial' states was considered the only reasonable solution; besides that, their populations consisted of many disparate ethnic groups speaking different languages and lacking any sense of common identity. These minority groups were considered undesirable, against whom the majority had to develop national defence strategies (Karpat 1997: 329-359). After its formation, Romania used all means at its disposal (the administrative, the educational, and military system, the church, and the media) to accelerate the process of constructing national identities. This kind of overall perception led to a turbulent, nationalistic, and irrational ethnic series of nation- and state-building processes, policies (Harris 2013: 53-70). A key factor in Romania's political development is the prioritization of centralization. As a result, political participation soon became restricted to a small segment of the population that was related to the ruling apparatus through the system of clientelism and public corruption (Crampton et al. 2021). 
As for the ethnic composition of Dobruja, most specialists agree on its multiethnic and multi-cultural aspect (Rădulescu et al. 1998), but they are arguing over which nationality was in majority or how and when the majority group came to live here. ${ }^{2}$ Adrian Rădulescu and Ion Bitoleanu claim that during the Russo-Turkish War of 1877-78 most of the Muslim population was evacuated to Bulgaria and Turkey. Similarly, part of the Lipovans and Ukrainians emigrated from the region, mostly to Ukraine. After the above-mentioned war had ended, the fairly empty territory of Dobruja was mostly filled with settlers from Romania's other regions and with the immigrants from other countries as part of a colonization process that was in line with Romania's planned, strategic considerations. According to Nicolae T. Negulescu - in consensus with Rădulescu and Bitoleanu -, in 1878, the Romanians reclaimed the region which between the years 1388 and 1418 was part of the united Romanian princedom (Negulescu 1928: 719-734). Thus, the right of sovereignty - supported by historical facts - belongs to the Romanian nation, into which residents of other nationalities will be integrated. In contrast to the abovementioned persons, Constantin Iordachi highlights that many politicians of the time were perceiving the province's geopolitical location and multi-ethnic population as a danger to the country's ethnic homogeneity and political stability. Not to mention that in fact after the 1877-1878 Russo-Turkish war had ended, Romania wanted to keep the regained territory of Southern Bessarabia (Budjak), resigning Dobruja (Iordachi 2002: 9-14).

As it has been many times underlined by the leaders of Tulcea and Constanța counties, Romania took over this region in a state of dilapidation, where the lack of infrastructure, state authorities, and basic resources were dominant, and the small number of people living here were battling disease and starvation. After the control over Northern Dobruja had been given to the new independent Romania, according to Nicolae T. Negulescu, former Prefect of Constanța County, it was necessary to include the region in the Romanian administrative-territorial system, creating three provisory counties. With the mobilization of large material resources, state institutions were created within two years, the necessary buildings, health centres, pharmacies, public baths, economic and cultural associations, banks, schools, and churches being brought to life (Negulescu 1928: 719-734). By the end of the year 1878, the region was regarded as an ancient Romanian land and an integral part of Romania's national heritage. But how exactly did the whole process take place?

2 Turks, Tartars, Romanians, Bulgarians, Russians, Ukrainians, Lipovans, Greeks, Armenians, Serbs, Jews, Italians, Albanians, and Arabs. 


\section{The Romanian Administrative-Territorial System and the Development of North Dobruja between 1878 and 1913}

The Romanian administration was created during the period of 1859-1866 in the course of the unification of Moldavia and Muntenia; the administrative-territorial system of these two autonomous principalities within the Ottoman Empire was also unified during this period. The country now called Romania was divided into counties (Ro: județ), ${ }^{3}$ the counties into districts (Ro: plasă, ocol), ${ }^{4}$ and the districts into communes and villages. A commune was made up of villages and farmsteads, which were the smallest administrative units. ${ }^{5}$ The head of a county was the prefect. In the districts, the vice-prefect was the leader in the beginning, but then, starting from 1918, this role was taken over by the praetor, while the towns and villages were led by a mayor (Ro: primar). The members of the county and local councils were elected based on census. As this short presentation shows, the constitution of Romania had very modern objectives, among which sharing of power (Ungureanu 2009).

The independence of Romania as a monarchy was officially proclaimed on 13 March 1881, after which event the former prince was crowned as Charles I; ${ }^{6}$ however, the Romanian state based on a constitutional monarchy started the transformation of its administrative-territorial system in 1878, even before the Congress of Berlin. The new, internationally recognized state borrowed its administrative-territorial, cultural, and educational models from France, just as it did during the above-mentioned period at the time of the unification of Moldavia and Muntenia (Raffay 1989).

Based on the administrative-territorial system of Romania, three provisory counties are created ${ }^{7}$ in Dobruja, with a total of nine districts, on 28-30 September 1878: ${ }^{8}$ Tulcea County with Măcin, Sulina, Tulcea, and Babadag; Constanța County with Constanța, Mangalia, and Hârşova; New Silistra County with Megidia and Silistra Nouă. The seats of the counties were in Tulcea, Constanța, and Rasova. ${ }^{9}$ According to the data provided by Leonida Colescu in 1878, Northern Dobruja had approximately 169,000 inhabitants (Iordachi 2002: 9-10). Immediately after the new administrative units and their institutions had been created, the functioning of

3 Until now, the mid-level settlements in Moldavia have been the lands (Ro: ținut).

4 In Muntenia, the district system had a tradition, but not in Moldavia.

5 The unified Moldavia and Muntenia principalities started using the name Romania from 1866 based on the new Constitution of the same year, issued on 1 July.

$6 \quad$ Karl von Hohenzollern-Sigmaringen.

7 Constanța, Tulcea, and Silistra Nouă.

8 Before the territory of Dobruja was divided between the Principality of Bulgaria and the Kingdom of Romania based on the 1864 administrative reform of the Ottoman Empire, the whole of the region had reorganized into the Danube Vilayet that had two sanjaks, Silistra and Tulcea. Within the Sanjak of Tulcea, which was given to Romania, there were thirteen kazas, and their capital was the town of Tulcea, which also gave the name of the sanjak.

9 Prefects of the counties: Constanța - Remus Opreanu, Tulcea - Gheroghe M. Ghica, Silistra Nouă - Grigore P. Cantilli. 
the three counties needed special procedures. First, every village was treated as an independent commune, and then the local council was formed, and the mayors took their offices in each of them by the end of the year. According to Remus Opreanu, the Prefect of Constanța County, this was a necessary step because the whole region was dominated by anarchy, the settlements were in a dilapidated condition, the population was starving, and a great number of robbers was looting the villages. ${ }^{10}$ The derogation from the law and the extension of control were necessary in order to ensure the stabilization of these conditions, to create living spaces, to ensure security and other basic needs. It is probable that due to the above causes the continuous changes were thought necessary by the authorities: e.g. both in the case of Tulcea and Constanța, the prefects were replaced, the seat of New Silistra County was first moved to Cernavodă and then to Medgidia already before April 1879 (Negulescu 1928: 719-734). However, Constatin Iordachi considers that this special administrative regime in the province was meant to give the government a free hand in implementing a gradual programme aimed at the socioeconomic, political, and ethnic assimilation of Dobruja's inhabitants. To confirm his theory, he invokes the political debate of the time between the liberal and conservative parties, which were focusing on the assimilation/dissimilation issue of the region. The Conservative Party was pleading for an autonomous, multicultural confessional organization in the region whereby each ethnic group would govern itself in its own language, whereas the Liberal Party desired the complete assimilation of the region with an administrative-territorial, cultural, and educational system directed from Bucharest (Iordachi 2002: 9-14). As we will see in more detail below, a decision was made to fully assimilate the region, the exact aspects of which strategy will be developed by 1882. In essence, this decision is the first step that the independent Romania will take with regard to the integration policy of a newly acquired territory.

Based on a new law regarding the reorganization of Dobruja promulgated on 9 May 1880, a new administrative-territorial division was implemented. Instead of the three counties, only two were created, Tulcea and Constanța, the latter now also comprising the whole of Silistra Nouă County. Tulcea County was made up of four ${ }^{11}$ districts and Constanța of five. ${ }^{12}$ Within the districts, both counties had seven townships; ${ }^{13}$ Tulcea had 56 communes made up of 120 villages and Constanța 72 communes made up of 301 villages. According to Dumitru Valentin Pătraşcu (2011), this administrative reorganization and the preceding implementation of laws regarding justice, tax system and customs service, land and forest management, a system similar to the other regions of the state was created in only two years. Although Dobruja was formally

10 The population of the region was around 135,000-140,000.

11 Babadag, Tulcea, Macin, and Sulina districts.

12 Constanța, Mangalia, Medgidia, Harsova, and Silistra Nouă.

13 Tulcea townships: Tulcea, Chilia Veche, Babadag, Sulina, Isaccea, Măcin, and Mahmudia; the townships of Constanța: Constanța, Medjidia, Cernavodă, Hîrşova, Mangalia, Cuzgun, and Ostrov. 
incorporated into Romania, it still had a separate, exceptional administrative regime. Thus, the inhabitants of the region gained their citizenships in 1878, but they did not gain political rights. After the 1880 law had come into force, they were theoretically able to exercise their political rights. Practically, from 1878 to 1908, the inhabitants of the region enjoyed only a local type of citizenship, but their political emancipation was only gradually validated in 1908-1913 (Iordachi 2002: 20-24). This means that every administrative-territorial unit and institution was governed by Romanians moved to Dobruja from other regions of the state. Following these measures, which meant to rebuild and repopulate the province, the boundaries of the counties were no more modified (Negulescu 1928: 722-732) though the districts of the region were reorganized several times (Lahovari 1902: 651-657). ${ }^{14}$ It is clear that the management of the region remained highly centralized even after a series of administrative reorganizations, a fact that indicates that until a clear assimilation of the area's inhabitants took place, the administrative tasks would be performed by external management.

Starting with 1879, the population of Constanța was on the rise, and in 1880 it had a population of 64,902, out of which 14,884 were Romanians, 14,974 Turkish, 22,584 Tartars, 8,492 Bulgarians, and 4,000 other nationalities. Tulcea County shows a similar tendency and ethnic composition. In the same period, the population of the latter county was 75,070. From 1881 onwards, the population of Dobruja is mostly filled with settlers from Romania's other regions and with the immigrants of other countries (Rădulescu et al. 1998: 358-360), a process that was in line with Romania's planned, strategic considerations. The significant number of the settlers is also confirmed by the fact that new villages were created for them, e.g. Făgăraşul Nou, Caramurat (Negulescu 1928: 723). Another important aspect was that, especially during the early years of the new administrative system, the Principality of Bulgaria encouraged ethnic Bulgarians to move from Northern Dobruja to Southern Dobruja (Rădulescu et al. 1998: 363-364). This could have resulted in a drop in population, but it was not the case as the empty villages were almost immediately colonized with the newly arrived settlers. Starting with 1880, Italians from Friuli and Veneto also settled in the northern regions of Dobruja: some worked in the granite mines of the Măcin Mountains, while others worked as simple farmers (Marian et al. 2008: 133-147). These population exchange practices suggest that they are part of a more complex plan. What we can see between 1879 and 1881 is practically the partial evacuation of the region, the reduction of its indigenous population, and then, as a second step, its replenishment from other regions of Romania and establishing settlements of ethnic groups belonging to different Latin language families.

There was a great number of factors defining the development of North Dobruja and its organization similar to the rest of Romania's other regions. As it was mentioned in the introduction, Romania took over this region in 1878 in a state of dilapidation, where the lack of infrastructure, state authorities, and basic resources

14 In 1892, 1897, and 1909. 
were dominant. The process of rebuilding the region and its infrastructure was rapid in order to replace and reshape the above-mentioned aspects but also to quickly assimilate local minorities (Iordachi 2002). In just two years, the infrastructure of public institutions, the buildings that accommodated them, and economic and educational institutions were established. Special attention was given to education, and one of the objectives was to aid the assimilation of the different nationalities. As an illustration of the above, the 19 newly built schools of Constanța County that operated between 1879 and 1880 had courses exclusively in Romanian language but also hired Muslim (Turkish and Tartar) teachers. ${ }^{15}$ One could see this as a gesture of good faith towards a community still in majority, but at the same time one could ask why none of these newly founded educational institutions were not exclusively made available for the Muslim community. Furthermore, it was a custom to send away pupils to Bucharest and Iaşi on a scholarship, and to be seen off by their colleagues and teachers on the day of their departure while the anthem of Romania was being played. The data regarding Tulcea County are scarcer, but the report of Prefect Paul Stănescu shows that in 1885 there were 105 educational institutions in the county. It is probable that the practices detailed regarding Constanța County were valid in this case as well, as the strategies of the central power regarding Dobruja were based on a unified vision (Negulescu 1928).

In 1881, 25 Romanian churches were built on the territory of Constanța County, and in 1882 the cathedral of Constanța was also finished, all these being financed by the state. During the same period, the local Romanian leaders encouraged the Muslim population to build mosques, but there is no information regarding whether the Romanian state offered any financing, which leads us to the conclusion that there were none. According to the Bulgarian historians, after 1885, the Romanian church authorities took control of all local churches, except two in the cities of Tulcea and Constanța, which managed to retain their traditional Slavic Bulgarian liturgy (Kosev et al. 1963). In contrast with the 25 Romanian churches built within one year, between 1879 and 1900, the ethnic Bulgarians built 15 new churches in North Dobruja (Rădulescu et al. 1998: 365). Although the lands and other possessions were not owned by a narrow layer of the local communities, these properties were still reallocated among the native and settled populations in order to 'ensure public welfare'. Ultimately, in 1882, monuments that commemorated the region's annexation to Romania and the symbols of the state were erected (Negulescu 1928: 722-727). Although the increase in the region's population can be attributed to those who moved largely from other regions of Romania, in terms of education policies and church construction directives, these strategies were primarily aimed at assimilating indigenous communities and not serving the newly arrived inhabitants.

By 1896, the population of Constanța County had doubled in comparison with the numbers of 1880, numbering a total of 112,227 , out of which 56,617 people declared

15 Previously, Constanța County had a total of 37 educational institutions. 
themselves Romanian. The number of educational institutions also rose: at this time, there were 83 schools. At the same time, at the intervention of D. Bănescu, building the road system of the county also started. Regarding the development of Tulcea County, details are to be found in Luca Ionescu's report. Compared to the year 1880, here the population had also almost doubled by 1904, counting 136,213, out of which 51,442 considered themselves Romanians. Ionescu openly and clearly assumed the fact that the most important achievement of the last 25 years had been the population, colonization of the Danube Delta with ethnic Romanians and the total assimilation of the multi-ethnic population, namely the national, confessional, economic, and political unification. The 1904 report of Constanța County detailed similar results and directives, and according to this the population of Constanța was 139,570 at the time, out of which 80,137 people considered themselves Romanians. At the same time, Prefect Scarlat Vârnav, by expressing his thoughts on expanding the territorial possessions of the county, also revealed Romania's simple strategy regarding Dobruja, i.e. his single and continuous activity regarding the region can only be the strengthening of the Romanian nation by growing the numbers of the population. In 1911, the population of Constanța County was 172,838, and then, in 1921, it increased to 176,989, out of which 119,304 declared themselves Romanian (Negulescu 1928: 719-734). So, by the early $20^{\text {th }}$ century, clear statements proved the intention of colonization as a strategy and goal underlying the artificial increase in the region's population.

After 1882, a well-transparent scheme was established among the many colonization strategies, defining four main categories that were implemented in the following order: (1) massive colonization with citizens from Romania's other regions; (2) colonization with ethnic Romanians from abroad; (3) colonization with ethnic groups of Latin origin, such as Italians, French, or Spanish people; (4) non-Latin foreign colonists. In addition to the massive colonization with ethnic Romanians of the region, other four main factors facilitated the assimilation of North Dobrogea: (1) the establishment of a highly centralized political and administrative regime; (2) the exclusion of Dobruja's non-Romanian economic elites from political rights; (3) cultural homogenization; (4) nationalization of landed property (Iordachi 2002: 28-32). Putting this strategy into practice, it is clear that in terms of the region's ethnic composition, homogenization was the primary goal and not the preservation of diversity and multiculturalism.

The next important change that affects Dobruja comes about in the first years of the $20^{\text {th }}$ century. The nations of the Balkans organized different movements in a great number of cases for various reasons, the results of which were revolts, rebellions. Taking advantage of the development that after the Italo-Turkish War of 1911 the Ottoman Empire was considerably weakened, Bulgaria, Greece, Montenegro, and Serbia created the League of Balkans in 1912, having the objective the total liberation of the territories they considered their own. They declared war to the Ottoman Empire in the same year, and thus the First Balkan War has started. Within 
six months, the League of Balkans emerged victorious, but due to the dissatisfaction with the results of the Treaty of London regarding the territories, the League broke up, and its former members, completed with the Ottoman Empire and Romania, started the Second Balkan War against Bulgaria. The second peace treaty was signed in August 1913 in Bucharest by Bulgaria, Greece, Montenegro, Romania, and Serbia, putting a definitive end to the Balkan War. Under the provisions of the peace treaty, Romania obtained South Dobruja from Bulgaria, ${ }^{16}$ including the fortress of Silistra and the town of Balchik (Jelavich 1996: 75-98).

\section{The Administrative-Territorial Changes of North and South Dobruja between 1913 and 1926}

Before South Dobruja became part of Romania, its administrative-territorial transformation had been slower compared to the northern territories annexed to Romania after 1878. The foundations for the development of the Principality of Bulgaria's state organization were laid with the help of the Russian Empire, and then in 1881 the framework and forms of administration were defined (Demeter et al. 2020: 155-225). The territory of the Principality of Bulgaria was divided into 21 administrative units (okrug), of which the territory of South Dobruja included Silistra and Varna counties. The counties were divided into districts (okolia) and these again into smaller areas (obshtina). The small areas with local administration contained several farmsteads, villages, and towns. Silistra had three and Varna five districts. ${ }^{17}$ The county system of Bulgaria was modified first in 1888 and then again in 1893, but none of these changes had a significant effect on the territory of South Dobruja. ${ }^{18}$ At the same time, it must be underlined that the three districts of Silistra were modified in $1888 .{ }^{19}$ During the period of 1900-1910, a great number of administrative-territorial changes were implemented, this time affecting both counties in South Dobruja. Among the three districts of Silistra, one was merged into Varna, one into Ruse, and the remaining one was completely dismembered, abolishing its independence. ${ }^{20}$ Varna County lost one of its districts from before 1900, but, being expanded with Kurt-Bunar ${ }^{21}$ District of Silistra, its territory did not actually change (Cannon 2019).

16 During the Second Balkan War, the Romanian generals used to call South Dobruja as Cardrilater, this name being in use today as well.

17 The districts of Silistra: Bazaurt, Khaskovo, Silistra; the districts of Varna: Balchic, Varna, Pazardzhik (Dobric from 1882), Khadzhioglu, and Dobrici.

18 First, the 21 counties are increased to 23, and then, by merging several counties, their final number is 20 .

19 The new district system: Ak-Kadzhilar, Kurt-Bunar, Silistra (Bazaurt and Khaskovo disappeared).

20 Ak-Kadzhilar can no longer be found in any of the counties.

21 Districts of Ruse County: Biala, Razgrad, Ruse, Silistra, Tutrakan; districts of Varna County: Balchik, Dobrich, Kurt-Bunar, Provadiia, Varna. 
As a result of signing the 1913 Bucharest Peace Treaty that ended the Balkan Wars, Cadrilater (Southern Dobruja) becomes part of Romania, and thus the number of the country's counties increases from 32 to 34 (Jelavich 1996). The Romanian authorities reorganize the Bulgarian administrative-territorial system of the region in the same year, creating Dobrici County out of the former Varna Okrug and Durostor County out of Silistra Okrug. While Dobrici was reorganized under the Romanian authority without major territorial changes, Durostor was expanded with the settlements of Constanța County's Ostrov District, thus increasing the territory it had under Bulgarian control. In Dobrici County, three districts were created with a total of 233 villages, ${ }^{22}$ and its seat became the town of Dobrici with which the Romanian authorities have organized three townships. ${ }^{23}$ The number of districts of the North Dobruja Constanța County was reduced to four from five, all except one being also renamed. ${ }^{24}$ The town of Ostrov and the neighbouring territories were reorganized into Durostor County. The latter would have four districts with a total of 195 villages, ${ }^{25}$ its seat became Silistra and with it there would be three townships. On 1 April 1914, just before the outbreak of WWI, both the name of Dobrici town and of the county were changed. The county would be given the name Caliacra of Greek origin, ${ }^{26}$ while the town would be called Bazargic. ${ }^{27}$ At the same time, the administrative-territorial reorganization took place in the region: similarly to North Dobruja, a fierce Romanization was started following the paradigms and practices detailed in the previous chapter. First, a decision was taken in Bucharest about assimilating the newly acquired territory without asking the local communities about their intentions. As a second step in the process, the immediate administrative-territorial reorganization and the nationalization of landed property were put into practice. In parallel, they established a highly centralized political and administrative regime, intentionally excluding South Dobruja's non-Romanian economic elites from political rights. The next step consisted in the implementation of colonization strategies described by Iordachi: the partial evacuation of the region, the reduction of its indigenous population, the population exchanges, replenishment from other regions of Romania, and establishing settlements of ethnic groups belonging to different Latin language families (Iordachi 2002: 28-32). The last step in the process was the cultural homogenization mostly by educational policies, language use restrictions, and church construction directives.

22 Balchik (72 settlements), Casim (63 settlements), Ezibei (98 settlements).

23 Dobrici, Balchik, Cavarna.

24 Thus, the four districts of the county are: Dunărea (seat at Hârşova), Mangalia (seat at Mangalia), Ovidiu (seat at Constanța), and Traian (seat at Megidia).

25 Accadanlar (48 settlements), Curtbunar (41 settlements), Silistra (63 settlements), and Turtucaia (43 settlements).

26 Kaliakra received its name from Cape Caliacra of the Black Sea.

27 Three centuries before 1882, it was called Hacioglu Pazarcik (small market); its founder, Hacioglu Bakal was, an Ottoman merchant. The Romanian Bazargic is derived from the Turkish Pazarcik. 
In 1913, the population of the territory just obtained from the Principality of Bulgaria had roughly a population of 300,000,2\% (6,000 people) of which considering themselves ethnic Romanians (Sweet 1957: 336). In the same year, the population of North Dobruja, which had been under Romanian authority for 35 years, numbered 380,430 persons, out of which 216,425 (56.8\%) declared themselves Romanian (Roman 1919). Totalling these numbers, when Dobruja's territory was united under Romanian control in 1913, the region's population was just over 680,000, out of which only 222,000 people, i.e. $33 \%$ of the population considered themselves Romanian (Boia 2001: 182). It must be mentioned that until the 1925 administrative reforms, the territory of North Dobruja's counties and districts did not change.

Except for a few years, South Dobruja remained part of Romania during WW2, with insignificant changes in the administrative-territorial composition, ${ }^{28}$ up until when the Treaty of Craiova ${ }^{29}$ was signed by Bulgaria and Romania on 7 September 1940 (Ciorbea 2017: 51-76). ${ }^{30}$ After Romania had entered WW1 as an ally of France and Russia, the Central Powers occupied many regions of Romania, including the whole of Dobruja. Starting with 1916, a German military general governorate was set up in Romania under Germany's control, which until 1918 represented the highest power in the state. Under the command of the general governorate, there were three military governorates, ${ }^{31}$ one of which in Dobruja (both in the North and South) was working under Turkish, Bulgarian, and German government (Balla 2017: 114-120). Shortly after the end of WW1, in accordance with the Treaty of Neuilly of 1919, Romania had regained its lost territories and within a few months had reinstated the administrative-territorial system from before 1916, a system that was changed only in 1925 when a new law for the unification of administration was adopted in the wake of organizing Greater Romania.

Greater Romania’s first administrative law adopted on 14 June 1925 was meant to unify the administration of the different regions, abolishing their characteristics (Lua 1925). Although starting with the adoption of the new administrative law all regulations came into force, the Parliament introduced an amending law on 22 December 1925 due to which the implementation of the first unifying administrativeterritorial law took place only on 1 January 1926 (Lmp 1925). In regard to Dobruja’s four counties, Tulcea suffered only minor changes, renaming the Sulina and Tulcea districts to Gurile Dunării and Topolog. ${ }^{32}$ At this time, the four districts of Tulcea

28 The Paris Treaty confirmed the 1940 borderline between the two countries.

29 According to the treaty, the ethnic Romanian (Aromanians and Megleno-Romanians, settlers from the other regions of Romania and natives) population was forced to leave the territories regained by Bulgaria, and in turn the Romanians drove the Northern Bulgarian minorities away; so, there was a population exchange.

30 During WW1, between 1916 and 1918, Bulgaria took the Cadrilater back from Romania.

31 Muntenia, Bucharest, and Dobruja.

32 Thus, the four districts of the county are: Babadag (seat at Babadag), Măcin (seat at Măcin), Gurile Dunării (seat at Tulcea), and Topolog (seat at Topolog). 
County included 155 villages, ${ }^{33}$ its seat remained the town of Tulcea, and the number of the town's communes was reduced from seven to five.$^{34}$ In the case of the other three counties, significant changes were implemented. The four districts of Constanța were increased to seven, and one of them was renamed. ${ }^{35}$ At this time, the seven districts of the county were made up of 202 villages, ${ }^{36}$ its seat remained at Constanța, and the number of the town's communes was increased from four to eight. ${ }^{37}$ In Caliacra County, a fourth district of forty settlements was created under the name Stejarul. In the case of Durostor County, a similar renaming was implemented by dividing Silistra into two: District Doimuşlar with 33 villages and District Ostrov with 30 settlements were created. As a result of the administrative-territorial reorganizations, the four districts of the newly created Caliacra encompassed 233 villages, ${ }^{38}$ its seat remained Bazargic, and it also retained the number of the communes. ${ }^{39}$ The five districts of Durostor County encompassed a total of 195 villages, ${ }^{40}$ retaining its seat at Silistra and also the number of the communes.

The regulations regarding the unification of administration manifested in measures meant to facilitate the assimilation of national minorities. As an example, one can highlight the law regarding elementary education adopted on 26 July 1926, which - as in the case of Szeklerland - did not favour Dobruja. Starting with the following academic year, paragraph 159 of the above mentioned law ordered the setting up of so-called 'culture zones' in the case of 20 counties $^{41}$ where the number of ethnic minorities was significant (Balogh 1996: 64). The essence of these provisions was to bring in ethnic Romanian teachers, offering significant financial aid for those who promoted the Romanian language and culture through their activities and worked in order to facilitate the assimilation of national minorities. The law ensured this financial aid for teachers for a period of ten years, and those who settled in the settlements in question were given a complimentary ten-acre property (Hamangiu 1926: 555).

33 Babadag (27 villages), Măcin (37 settlements), Gurile Dunării (57 settlements), and Topolog (34 settlements).

34 Communes of Tulcea County: Tulcea, Babadag, Sulina, Isaccea, and Măcin.

35 Thus, the seven districts of the county are: Cernavodă (seat at Cernavodă), Dunărea (seat at Hârşova), Ferdinand I (seat at Constanța), Mangalia (seat at Mangalia), Megidia (seat at Megidia), Negru Vodă (seat at Negru Vodă), and Traian (seat at Corvin).

36 Cernavodă (15 settlements), Dunărea (26 settlements), Ferdinand I (37 settlements), Mangalia (24 settlements), Megidia (26 settlements), Negru Vodă (37 settlements), and Traian (37 settlements).

37 Communes of Constanța County: Constanța, Carmen-Sylva, Cernavodă, Hârşova, Mangalia, Megidia, Techirghiol.

38 Balchik (72 settlements), Casim (63 settlements), Ezibei (58 settlements), and Stejarul (40 settlements).

39 Dobrici, Balchik, Cavarna.

40 Accadanlar (48 settlements), Curtbunar (41 settlements), Silistra (33 settlements), Turtucaia (43 settlements), and Ostrov (30 settlements).

41 Ten in Transylvania: Bihor, Sălaj, Maramureş, Hunedoara, Odorhei, Ciuc, Trei Scaune, MureşTurda, Turda-Arieş; four in Bukovina: Vişnița, Văscăuți, Cotmani, Zastavna; four in Bessarabia: Hotin, Tighina, Cetatea-Albă, Ismail; two in South Dobruja (Cadrilater): Durostor, Caliacra. 
Beyond the feeling of life resulted from this discriminative phenomenon (Tóth Sz. 2009: 525-532), ${ }^{42}$ the indignation of the local communities was fuelled by the fact that the funds set apart for the building of schools were used only to build schools where the language of education was Romanian, and only those school buildings were repaired where the institution was then transformed into a Romanian one.

So far, Romania had largely succeeded in enforcing its assimilation strategies, and from this point on the region was treated in historiography as an integral part of the Romanian Old Kingdom. In spite of its highly individualized geographical and unique, ethnically diverse demographic character, the case of Dobruja as a distinguished region received only limited attention. This aspect can be explained by the process of the Romanian nation- and state-building and the aspect of the national consolidation of Greater Romania, which focuses almost unilaterally on the validation of the country's rights to the region (Iordachi 2002).

\section{Conclusions}

After the region had been broken off from the Ottoman Empire, Dobruja's administrative-territorial system changed several times in order to acclimatize and maintain the Romanian rule over the region. After Dobruja had been annexed to Romania, the state's central powers started a rapid administrative-territorial reorganization to begin the assimilation process of the local ethnicities, termed by them integration. In fact, this so-called integration manifested itself in implementing the strategies of the state leadership, supporting mass migration in the region by bringing settlers here in large groups, more precisely different communities from other Romanian regions. Taking this aspect into account, it can be stated that the political elite took the first step towards the colonization of Dobruja.

In addition to the region's massive colonization with ethnic Romanians, four main reasons facilitated assimilating the region: first of all, the nationalization of landed property, after which the establishment of a highly centralized political and administrative regime, the exclusion of Dobruja's non-Romanian economic elites from political rights, and, last but not least, cultural homogenization. Putting this assimilation strategy into practice, it is clear that in terms of the ethnic composition of the region, homogenization was the primary goal and not the preservation of diversity and multiculturalism. All these factors contributed to the Romanian nation- and state-building process, which later, especially after WWI, was considered a successful model and an example to follow in the case of Transylvania, the Székelyland, Partium, Banat, Bukovina, and Bessarabia.

42 In the case of Romanians coming from other counties, we are talking about positive discrimination, while the local Romanian and ethnic Hungarian population was discriminated. 


\section{References}

BALLA, Tibor. 1998. Bulgária felszabadulásának és az önálló bolgár hadsereg létrejöttének 120. évfordulója. Szófia: Nemzetközi tudományos konferencia, 4-9. Hadtörténelmi Közlemények 1998/2 https://efolyoirat.oszk. hu/00000/00018/00005/pdf/k2.pdf (downloaded on: 11 November 2021).

2017. Ausztria-Magyarország részvétele a megszállott Románia katonai kormányzásában, 1916-1918. Hadtörténelmi Szemle 1: 114-120.

BALOGH, Júlia. 1996. Az erdélyi hatalomváltás és a magyar közoktatás 1918-1928. Budapest: Püski Kiadó Kft.

BIRCH, Anthony H. 1989. Nationalism and National Integration. London: Routledge. BOIA, Lucian. 2001. History and Myth in Romanian Consciousness. Budapest: Central European University Press.

BRUBAKER, Rogers. 1996. Nationalism Reframed: Nationhood and the National Question in the New Europe. Cambridge: Cambridge University Press.

CANNON, Angela. 2019. Administrative-Territorial Divisions in Bulgaria. Bulgarian Statistics - A Resource Guide. In: Springshare - Library of Congress Legal [Online]. [Cited on: 12 July 2021] https:/guides.loc.gov/bulgarian-statistics/ administrative-territorial-divisions.

CIORBEA, Valentin. 2017. Situația dobrogei între anii 1916-1918 în izvoare germane istorice de epocă. Annals of the Academy of Romanian Scientists, Series on History and Archaeology Sciences 9(2): 51-76.

COCIU, Mircea. 1993. Spațiul istoric şi etnic românesc (vol. 3). Bucharest: Editura Militară.

CRAMPTON, Richard J.-ALLCOCK, John B.-DANFORTH, Loring. 2021. In: Encyclopedia Britannica - 'Balkans' [Online]. [Cited on: 22 October 2021] https://www.britannica.com/place/Balkans.

DEMETER, Gábor et al. 2020. Balkán kronológia I. (Birodalmak szorításában, 1700-1878). Budapest-Szófia: Institut za Istoricheski Izsledvaniya BAN Bölcsészettudományi Kutatóközpont, Történettudományi Intézet. 155-225.

HAMANGIU, Constantin N. 1926. Codul general al României, vol. XI-XII, Legi uzuale 1922-1926. Bucharest: Alcalay \& Co.

HARRIS, Mylonas. 2013. The Politics of Nation-Building: Making Co-Nationals, Refugees, and Minorities. Cambridge: Cambridge University Press. 53-70.

IORDACHI, Constatin. 2000. 'A románok Kaliforniája' - a román határ kiterjesztése Észak-Dobrudzsában 1878-1913. Replika 41-42: 241.

2002. Citizenship, Nation- and State-Building: The Integration of Norther Dobrogea into Romania, 1878-1913. In: CHASE, William-DONNORUMMO, BobLINDEN, Ronald H. (eds), The Carl Beck Papers for Russian and East European Studies. Pittsburgh: University of Pittsburgh. 1-86. 
JELAVICH, Barbara. 1996. A Balkán története II. Budapest: Osiris. 75-98.

KARPAT, Kemal Haşim. 1997. The Balkan National States and Nationalism: Image and Reality. Islamic Studies 2-3(36): 329-359.

KOSEV, Dimitur-HRISTOV, Hristo-ANGELOV, Dimitur. 1963. A Short History of Bulgaria. Sofia: Foreign Languages Press.

LAHOVARI, George Ioan. 1902. Marele dicționar geografic al României (vol. II, V). Bucharest: Stab. Grafic J. V. Socecu [Online]. 651-657. https://archive.org/ details/MareleDictionarGeograficAlRominiei5/mode/2up?view=theater [Cited on: 12 July 2021].

LMP. 1925. Lege privind modificarea unor prevederi (Law on Amending Certain Provisions). Monitorul Oficial al Regatului României (MO, Official Monitor of the Kingdom of Romania) 283 (22 December 1925).

LUA. 1925. Lege pentru unificarea administrativă (Law for Administrative Unification). Monitorul Oficial al Regatului României (MO, Official Monitor of the Kingdom of Romania) 128. (14 July 1925).

MARIAN, Moise-MIHALCEA, Alexandru. 2008. Italienii din Dobrogea - Mica Italie a unor meşteri mari. 150 de ani de istorie comună. In: Virgil COMAN (ed.), Dobrogea - model de conviețuire multietnică şi multiculturală. Constanța: Editura Muntenia. 133-147.

MERRIAM-WEBSTER. 2021. Nation-State [Online]. https://www.merriam-webster. com/dictionary/nation-state [Cited on: 5 November 2021].

NEGULESCU, Nicolae T. 1928. Administrația în Dobrogea veche. Analele Dobrogei IX(1): 719-734.

PĂTRAŞCU, Dumitru Valentin. 2011. Regulamentul privind organizarea administrativă a Dobrogei. Litua - studii şi cercetări XIII. Târgu Jiu: Muzeul Județean Gorj „Alexandru Ştefulescu”. 101-114.

RĂDULESCU, Adrian-BITOLEANU, Ion. 1998. Istoria Dobrogei. Constanța: Ex Ponto.

RAFFAY, Ernő. 1989. A vajdaságoktól a birodalomig. Szeged: JATE.

ROMAN, Jean N. 1919. La population de la Dobrogea. D’apres le recensement du $1^{\mathrm{er}}$ janvier 1913. In: DEMETRESCU, Anghel (ed.), La Dobrogea Roumaine. Études et documents. Bucharest: L’Institut pour l'étude de L'Europe sudorientale.

SWEET, Paul R. et al. 1957. Documents on German Foreign Policy, 1918-1945. Washington: U.S. Government Printing Office.

SZABÓ, Pál. 2014. Hol is van Szkítia? Egy földrajzi fogalom történeti topográfiai változásairól. Belvedere Meridionale 26(3): 22-48.

TÓTH, Sándor. 2009. A román politikai gondolkodás geopolitikai alapjai. PhD dissertation. Budapest: Zrínyi Miklós Nemzetvédelmi Egyetem.

TÓTH, Szilárd. 2009. A „kultúrzóna” - Szükség vagy politikai cél? Gondolatok a két világháború közötti román tanügyi törvények kapcsán. Acta Siculica (A Székely 
Nemzeti Múzeum Évkönyve). Sfântu Gheorghe: Székely Nemzeti Múzeum. 525532.

UNGUREANU, Adelin. 2009. Istoria constituțională a României. Analele Universității „Constantin Brâncuşi” din Târgu Jiu, Seria Ştiințe Juridice 2: 129142. 